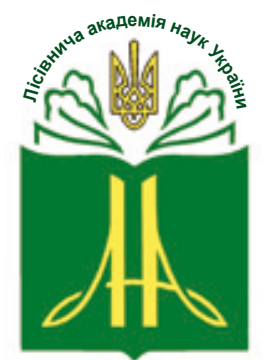

Forestry Academy of Sciences of Ukraine
Наукові праці Лісівничої академії наук України Proceedings of the Forestry Academy of Sciences of Ukraine http://fasu.nltu.edu.ua https://doi.org/10.15421/411926

Article received 2019.04.30

Article accepted 2019.12.26
ISSN 1991-606X print

ISSN 2616-5015 online

(a) $\triangle$ Correspondence author Yulian Kahaniak

kaganiak@yahoo.ca
General Chuprynka st., 103, Lviv, 79057, Ukraine

\title{
Структура соснових деревостанів району видобутку бурштину у північно-східній частині Західного Полісся
}

\author{
Л.І. Копій ${ }^{1}$, Ю.Й. Каганяк², С.Л. Копій ${ }^{3}$, В. М. Сухович ${ }^{4}$, М.Л. Копій ${ }^{5}$, І. В. Фізик ${ }^{6}$
}

Господарська діяльність державного підприємства «Клесівське лісове господарство», що розташоване у північно-східній частині Західного Полісся, характеризується комплексним використанням природних ресурсів, які знаходяться на території лісового фонду. Лісові екосистеми є джерелом деревини та недеревних лісових ресурсів, протектором ерозії грунту тощзо. Одночасно на території лісогосподарського підприємства здійснюється нелегальний видобуток бурштину. Таке негативне втручання зумовлює істотне пошкодження або повне знищення деревостанів і рослинного покриву.

Дослідження здійснювали з метою актуалізащії лісотаксаџійних показників соснових деревостанів на ділянках лісового фонду ідентичних до тих, які порушені внаслідок видобутку бурштину, з наступним аналізом структури деревного запасу. Об'єктом дослідження є чисті та мішані соснові деревостани на землях, які не порушені бурштиновими розробками, в умовах вологого субору на території лісового фонду ДП «Клесівське ЛГ», щуо за структурою відповідають пошкодженим. Предметом дослідження є структура деревного запасу зазначеного об'єкту.

Виявлено сімнадиять об'єктів, подібних за породним складом деревостанів. Запас для кожного елемента лісу поділено на десять рівновеликих частин. Встановлено мінливість частки запасу сосни звичайної, розподіленого за рівновеликими частинами. Виділено п'ять типів розподілу запасу сосни за рівновеликими частинами деревостану. Тип розподілу частки запасу сосни детермінований деревною породою, групою віку та показником мінливості діаметра стовбура. Встановлені особливості доиільно використовувати при відтворенні деревостанів на ділянках, порушених під час видобуванні буритину.

Копій Леонід Іванович - академік Лісівничої академії наук України, доктор сільськогосподарських наук, завідувач кафедри екології, професор. Національний лісотехнічний університет України, вул. Генерала Чупринки, 103, м. Львів, 79057, Україна. Тел.: +38-067-75034-66. E-mail: kop.1@i.ua ORCID https://orcid.org/0000-0001-6672-3904

2 Каганяк Юліан Йосипович - академік Лісівничої академії наук України, доктор сільськогосподарських наук, професор кафедри лісової таксації та лісовпорядкування. Національний лісотехнічний університет України, вул. Генерала Чупринки, 103, м. Львів, 79057, Україна. Тел.: +38-067-587-42-66. E-mail: kaganiak@yahoo.ca; y.kaganyak@nltu.edu.ua ORCID http://orcid.org/0000-0002-9215-3922

3 Копій Сергій Леонідович - член-кореспондент Лісівничої академії наук України, кандидат сільськогосподарських наук, доцент кафедри лісівництва. Національний лісотехнічний університет України, вул. Генерала Чупринки, 103, м. Львів, 79057, Україна. Тел.: +38097-440-98-20. E-mail: s.kopiy@email.ua ORCID https://orcid.org//0000-0002-7322-7244

4 Сухович Віталій Миколайович - аспірант кафедри екології. Національний лісотехнічний університет України, вул. Генерала Чупринки, 103, м. Львів, 79057, Україна. Тел.: +38-067-362-09-77. E-mail: suhovich_den@ukr.net ORCID https://orcid.org/0000-0001-8701-3135

Копій Марія Леонідівна - кандидат сільськогосподарських наук, асистент кафедри екології. Національний лісотехнічний університет України, вул. Генерала Чупринки, 103, м. Львів, 79057, Україна. Тел.: +38-097-440-98-20. E-mail: marykop16@ukr.net ORCID https:// orcid.org/ 0000-0003-4355-5543

6 Фізик Ігор Васильович - член-кореспондент Лісівничої академії наук України, кандидат сільськогосподарських наук, докторант кафедри екології. Національний лісотехнічний університет України, вул. Генерала Чупринки, 103, м. Львів, 79057, Україна. Тел.: +38-067362-15-55. E-mail: igor240265@gmail.com ORCID https://orcid.org/ 0000-0003-4247-2519 
Соснові деревостани, які використані для порівняльного аналізу, відносяться до одного типу лісу та однієї групи віку і характеризуються високою дисперсністю бонітету та відносної повноти. Структурний аналіз вказує на вагомість впливу чинника розробки буритину на величину сировинних втрат.

Ключові слова: структура лісостанів; запас; рівновелика частина; сосна; показник мінливості.

Вступ. Лісовпорядні рекомендації спрямовують діяльність лісогосподарських підприємств на комплексне використання лісових ресурсів. Екологоекономічні аспекти моделі комплексного використання лісових ресурсів конкретної території знайшли своє відображення в наукових літературних джерелах (Tunytsya, 2002) та втілені у практику.

Тривалий час на землях лісового фонду поліського регіону здійснюють використання не лише лісових ресурсів. Зокрема, на частині території ДП «Клесівське ЛГ» провадять видобуток бурштину. Із теорії загальної екології відомі вірогідні зв'язки, які встановляться між видобутком мінеральних природних ресурсів (бурштину) та лісовим фітоценозом (Kucheriavy, 2010). Висока інтенсивність і надмірні обсяги добутого мінералу можуть бути причиною деструктивних змін у лісовому фітоценозі. В перспективі таке необгрунтоване втручання веде до заміни лісової формації. Внаслідок такої діяльності на низці ділянок лісового фонду істотно ускладнюється реалізація плану лісогосподарських заходів. Внаслідок активного видобування бурштину істотно порушуються не тільки структура деревостанів, але й грунтові умови, вологість грунту, лісова підстилка, гідрологічні умови, рельєф теритоpiï (Hordijchuk, 2013, Kornienko, 2014). Видобуток мінералу 3 використанням потужних водяних помп призводить до значного порушення рельєфу місцевості, формуванню значних вирв, внутрішньогрунтових пустот, що створює істотні загрози під час здійснення лісогосподарських заходів (рис. 1).

Сформовані на землях після видобутку бурштину соснові деревостани, апріорі, будуть характеризуватись дещо іншим перебігом ростових процесів i темпами нагромадження деревного запасу. Деградовані грунти зумовлять формування менш продуктивних деревостанів (Reida, 2015). Зрозуміло, що практична реалізація концепції комплексного використання природних ресурсів на таких таксаційних виділах позначиться і на структурних особливостях ростучих там деревостанів. Тому завданням досліджень було передбачено здійснення оцінки системи лісогосподарських заходів (початок і завершення догляду у різних за складом і віковою структурою деревостанах в аналізованих умовах, інтенсивність вибірки другорядних і головних деревних порід під час проведення доглядових рубок, методи відбору дерев в рубку тощо) для опрацювання алгоритму формування корінних деревостанів на порушених внаслідок видобутку бурштину ділянках. Вчасне оцінювання змін у таких деревостанах, подальше розроблення науково обгрунтованих рекомендацій щодо планування комплексу лісогосподарських заходів, на наш погляд, є актуальними завданнями 3 погляду відтворення корінних та високопродуктивних деревостанів у зазначених умовах.

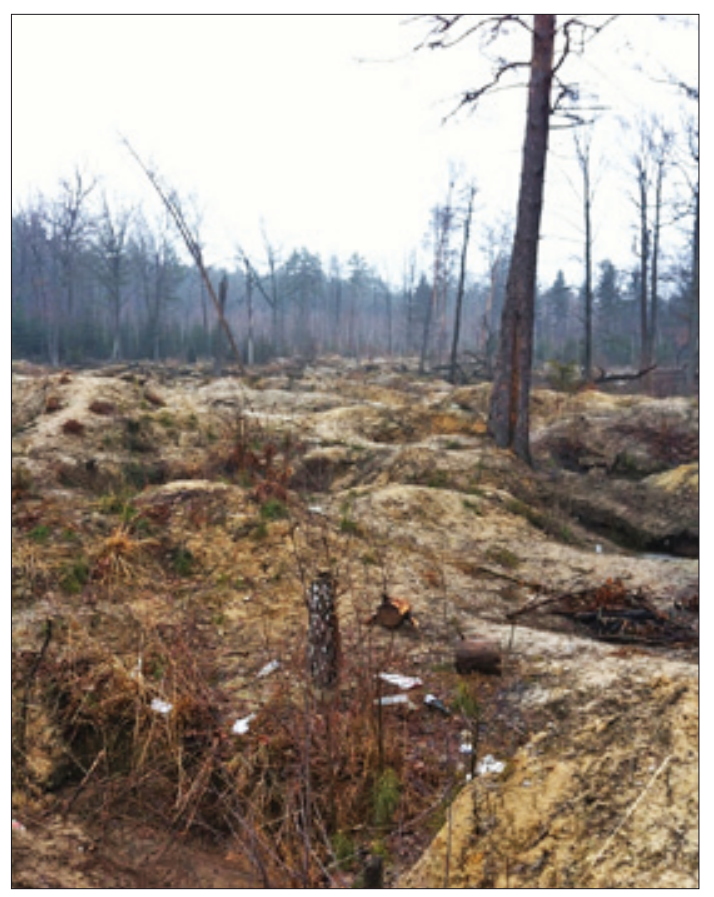

Рис. 1. Загальний вигляд ділянки середньовікового соснового деревостану після видобутку бурштину

Дослідження здійснювали з метою таксації соснових деревостанів на ділянках лісового фонду лісогосподарського підприємства, непорушених внаслідок видобутку бурштину, які є подібними за лісівничо-таксаційними характеристиками до деревостанів, знищених під час бурштиновидобування.

Опис об'скта та методики досліджень. Об'єктом дослідження є чисті та мішані соснові деревостани в умовах вологого субору на землях, які за лісорослинними умовами є подібними до земель, порушених бурштиновими розробками, на території лісового фонду державного підприємства «Клесівське лісове господарство». Предметом дослідження є структура деревного запасу зазначеного об'єкту. Мета дослідження полягала у вивченні особливостей формування соснових насаджень в умовах вологого субору з вивченням нагромадження деревини під впливом застосованої системи лісогосподарських заходів і термінів іiі проведення. Встановлені параметри корінних соснових деревостанів дають змогу опрацювати принципи вирощування високоповнотних і високопродуктивних мішаних (за участю дуба звичайного, берези повислої та вільхи чорної) лісостанів в умовах порушених територій.

Обстеження таксаційних виділів лісового фонду підприємства дало змогу виявити 17 ділянок, 
які за лісівничо-таксаційними характеристиками подібні до соснових деревостанів, що були знищені внаслідок видобутку бурштину. Вихідні дані про соснові деревостани представлені кількісними переліками дерев за елементами лісу, ступенями товщини та категоріями технічної придатності, а також висотами, заміряними у 3-5 дерев для кожної ступені товщини. 3 цією метою використано методику перелікової таксації із візуальним встановленням окремих лісівничо-таксаційних ознак (виду рослини; типу лісу; категорії технічної придатності дерева тощо). Методику перелікової таксації в достатньому обсязі висвітлено у вітчизня- ній науково-навчальній літературі (Tsuryk, 2000, Strochynskyy, 2006).

Таксаційні показники розраховано за загальноприйнятими формулами у лісовій таксації (Vorobjov, 1953, Jonson., Lion, 1980, Kahaniak, 2005, 2006, Strochynskyy, Kashpor, Berezivskyy, 2007, Strochynskyy, Kashpor, 2007).

Таксаційні виділи представлені чистими та мішаними сосновими деревостанами. Пробні ділянки закладені в соснових деревостанах, які відносяться до двох вікових груп - середньовікових і стиглих.

Лісотаксаційну характеристику соснових деревостанів на пробних ділянках подано в табл. 1.

Таблиия 1

Лісівничо-таксаційна характеристика соснових деревостанів, характерних для умов вологого субору

\begin{tabular}{|c|c|c|c|c|c|c|c|c|c|c|c|c|c|}
\hline Код & Лісництво & Кв. & Вид. & Порода & Кпд & $\mathrm{N}$ & $\mathrm{A}$ & $\mathrm{D}$ & $\mathrm{H}$ & M & $\mathrm{C}$ & $\mathrm{P}$ & Б \\
\hline 1 & 2 & 3 & 4 & 5 & 6 & 7 & 8 & 9 & 10 & 11 & 12 & 13 & 14 \\
\hline \multirow[t]{3}{*}{2808} & Ясногірське & 22 & 4.4 & Сосна & 0,70 & 799 & 48 & 18,2 & 17,9 & 172 & 10 & 0,47 & I \\
\hline & & & & Береза & & 4 & & 13,5 & 14,2 & 0 & 0 & 0,00 & \\
\hline & & & & Разом & & 803 & & & & 172 & 10 & 0,48 & \\
\hline 2809 & Ясногірське & 9 & 18.2 & Сосна & 0,30 & 313 & 49 & 17,0 & 17,4 & 58 & 10 & 0,16 & I \\
\hline \multirow[t]{3}{*}{2810} & Ясногірське & 9 & 18.1 & Сосна & 0,40 & 438 & 49 & 17,4 & 17,6 & 84 & 10 & 0,24 & I \\
\hline & & & & Береза & & 5 & & 8,0 & 11,3 & 0 & 0 & 0,00 & \\
\hline & & & & Разом & & 443 & & & & 84 & 10 & 0,24 & \\
\hline 2811 & Ясногірське & 1 & 38.1 & Сосна & 0,50 & 636 & 49 & 19,7 & 18,9 & 168 & 10 & 0,43 & I \\
\hline 2815 & Ясногірське & 3 & 25.2 & Сосна & 0,20 & 415 & 49 & 17,5 & 17,7 & 80 & 10 & 0,22 & I \\
\hline \multirow[t]{3}{*}{160} & Федорівське & 39 & 12.9 & Сосна & 0,40 & 250 & 44 & 33,5 & 25,5 & 254 & 10 & 0,48 & $\mathrm{I}^{\mathrm{c}}$ \\
\hline & & & & Береза & & 80 & & 14,4 & 14,6 & 9 & 0 & 0,05 & \\
\hline & & & & Разом & & 330 & & & & 263 & 10 & $\mathbf{0 , 5 3}$ & \\
\hline 118 & Клесівське & 40 & 13.1 & Сосна & 0,10 & 980 & 89 & 20,1 & 17,5 & 246 & 10 & 0,70 & IV \\
\hline \multirow[t]{3}{*}{600} & Любонське & 4 & 27.1 & Сосна & 0,80 & 438 & 48 & 15,2 & 15,0 & 57 & 7 & 0,20 & II \\
\hline & & & & Береза & & 351 & & 12,4 & 12,0 & 24 & 3 & 0,18 & \\
\hline & & & & Разом & & 789 & & & & 81 & 10 & 0,38 & \\
\hline 604 & Любонське & 1 & 18.2 & Сосна & 0,10 & 1000 & 44 & 12,9 & 13,6 & 87 & 10 & 0,34 & III \\
\hline 609 & Любонське & 8 & 3.5 & Сосна & 0,50 & 682 & 49 & 18,3 & 16,2 & 137 & 10 & 0,43 & II \\
\hline \multirow[t]{4}{*}{$73 a$} & Федорівське & 67 & 15.3 & Сосна & 0,60 & 247 & 89 & 34,4 & 25,8 & 268 & 9 & 0,50 & II \\
\hline & & & & Береза & & 52 & & 18,0 & 16,3 & 9 & 0 & 0,05 & \\
\hline & & & & Вільха & & 82 & & 17,4 & 16,0 & 15 & 1 & 0,09 & \\
\hline & & & & Разом & & 380 & & & & 292 & 10 & 0,64 & \\
\hline \multirow[t]{4}{*}{$45 \mathrm{a}$} & Федорівське & 37 & 30.2 & Сосна & 0,70 & 296 & 88 & 25,1 & 21,3 & 147 & 8 & 0,33 & II \\
\hline & & & & Береза & & 56 & & 15,3 & 14,9 & 7 & 0 & 0,04 & \\
\hline & & & & Вільха & & 121 & & 16,2 & 15,4 & 19 & 1 & 0,12 & \\
\hline & & & & Разом & & 473 & & & & 173 & 10 & 0,49 & \\
\hline \multirow[t]{3}{*}{$10 \mathrm{a}$} & Федорівське & 36 & 1 & Сосна & 0,40 & 483 & 88 & 29,3 & 24,7 & 363 & 10 & 0,71 & II \\
\hline & & & & Береза & & 65 & & 13,2 & 14,2 & 6 & 0 & 0,04 & \\
\hline & & & & Разом & & 548 & & & & 369 & 10 & 0,74 & \\
\hline \multirow[t]{3}{*}{$43 a$} & Федорівське & 23 & 27 & Сосна & 0,70 & 517 & 88 & 20,4 & 19,0 & 154 & 9 & 0,40 & III \\
\hline & & & & Береза & & 33 & & 23,9 & 18,5 & 11 & 1 & 0,05 & \\
\hline & & & & Разом & & 550 & & & & 165 & 10 & 0,44 & \\
\hline
\end{tabular}


Продовж. табл. 1

\begin{tabular}{|c|c|c|c|c|c|c|c|c|c|c|c|c|c|}
\hline 1 & 2 & 3 & 4 & 5 & 6 & 7 & 8 & 9 & 10 & 11 & 12 & 13 & 14 \\
\hline \multirow[t]{4}{*}{$30 \mathrm{aa}$} & Федорівське & 21 & 26 & Сосна & 0,30 & 137 & 93 & 32,6 & 25,6 & 133 & 8 & 0,25 & II \\
\hline & & & & Береза & & 87 & & 24,8 & 18,8 & 32 & 2 & 0,14 & \\
\hline & & & & Осика & & 13 & & 22,4 & 17,9 & 4 & 0 & 0,02 & \\
\hline & & & & Разом & & 237 & & & & 169 & 10 & 0,41 & \\
\hline 50 & Клесівське & 40 & 9.1 & Сосна & 0,10 & 1220 & 46 & 14,7 & 14,2 & 145 & 10 & 0,54 & II \\
\hline \multirow[t]{3}{*}{62} & Клесівське & 31 & 37.1 & Сосна & 0,20 & 460 & 48 & 26,6 & 24,0 & 278 & 9 & 0,56 & $\mathrm{I}^{\mathrm{b}}$ \\
\hline & & & & Береза & & 110 & & 19,4 & 17,2 & 24 & 1 & 0,11 & \\
\hline & & & & Разом & & 570 & & & & 301 & 10 & 0,67 & \\
\hline
\end{tabular}

Примітки. Спд - площа пробної ділянки, на якій здійснено перелік дерев, га; N - кількість дерев, шт. га ${ }^{-1}$; А - середній вік переважаючої деревної породи, років; D - середній діаметр елемента лісу, см; Н - середня висота елемента лісу, м; $\mathrm{M}$ - запас елемента лісу, ${ }^{3} \cdot{ }^{-1}{ }^{-1}$; C - частка елементу лісу в деревостані, одиниць; Р - відносна повнота елемента лісу; Б - клас бонітету переважаючої деревної породи.

Стиглі соснові деревостани характеризуються значним коливанням класу бонітету (від IV до II) та відносної повноти (від 0,4 до 0,7$)$. В основному, це чисті соснові деревостани або з невеликою домішкою (близько $10 \%$ ) берези.

Середньовікові соснові деревостани характеризуються високим бонітетом. Індекс класу бонітету змінюється від II до Ic. Відносна повнота таких деревостанів також різна, змінюючись від 0,2 до 0,7 . За складом соснові деревостани є чистими та мішаними. Частка сосни коливається від 10 до 7 одиниць. Як домішка у соснових насадженнях трапляються береза повисла, вільха чорна та осика.

Структуру запасу конкретного деревостану представлено у вигляді розподілу цього показника за 10ма рівновеликими частинами. Рівновелика частина встановлюється, як 1/10 від загальної кількості дерев. Алгоритм розподілу запасу за 10 -ма рівновеликими частинами наведено у попередніх наукових працях (Agij, Kopiy, Fizyk, Kahaniak, Kopiy, 2016, Kopiy et. al., 2014, Gonchar, Kopiy, Kahaniak, Kopiy, 2012, Kopiy, Kahaniak, Meleshchuk, 2008). Teopeтичною основою розподілу запасу елемента лісу на рівновеликі частини є дециль. Вихідними даними для структуризації запасу за рівновеликими частинами $є$ перелік кількості дерев за ступенями товщини та модель залежності висоти дерева від діаметра стовбура на висоті 1,3 м.

Результати дослідження та їх аналіз. В результаті опрацювання первинних даних переліку дерев на пробних ділянках за вищезгаданою в літературних джерелах методикою отримано розподіл запасу, диференційованого за елементами лісу та рівновеликими частинами деревостану для двох вікових груп насаджень (стиглих і середньовікових).

Підсумок розрахованої структури запасу для соснових деревостанів на території лісового фонду підприємства на пробних ділянках подано в табл. 2 .

Таблиия 2

\section{Розподіл запасу сосни за групами віку та рівновеликими частинами деревостану} на території лісового фонду ДП «Клесівське ЛГ»

\begin{tabular}{|c|c|c|c|c|c|c|c|c|c|c|}
\hline \multirow{2}{*}{$\begin{array}{c}\text { Код } \\
\text { пробної ділянки }\end{array}$} & \multicolumn{10}{|c|}{ Частка запасу сосни за рівновеликими частинами деревостану, \% } \\
\hline & 1 & 2 & 3 & 4 & 5 & 6 & 7 & 8 & 9 & 10 \\
\hline \multicolumn{11}{|c|}{ Середньовікові деревостани } \\
\hline 2808 & 1 & 3 & 4 & 6 & 7 & 9 & 11 & 13 & 17 & 29 \\
\hline 2809 & 2 & 4 & 5 & 6 & 7 & 8 & 10 & 12 & 16 & 31 \\
\hline 2810 & 2 & 4 & 6 & 7 & 8 & 9 & 10 & 13 & 16 & 25 \\
\hline 2811 & 2 & 3 & 5 & 6 & 7 & 9 & 11 & 13 & 16 & 29 \\
\hline 2815 & 3 & 5 & 6 & 7 & 8 & 9 & 10 & 12 & 15 & 25 \\
\hline 160 & 1 & 3 & 5 & 7 & 9 & 11 & 12 & 14 & 16 & 23 \\
\hline 600 & 1 & 2 & 3 & 4 & 6 & 8 & 11 & 14 & 19 & 33 \\
\hline 604 & 2 & 2 & 3 & 4 & 5 & 7 & 9 & 13 & 20 & 36 \\
\hline 609 & 1 & 2 & 4 & 6 & 7 & 9 & 11 & 14 & 18 & 30 \\
\hline 50 & 1 & 2 & 2 & 3 & 5 & 7 & 10 & 14 & 20 & 36 \\
\hline 62 & 1 & 4 & 5 & 7 & 8 & 10 & 12 & 14 & 17 & 23 \\
\hline \multicolumn{11}{|c|}{ Стиглі деревостани } \\
\hline 118 & 3 & 5 & 6 & 7 & 8 & 9 & 11 & 13 & 16 & 22 \\
\hline
\end{tabular}


Продовж. табл. 2

\begin{tabular}{lllllllllll}
\hline $73 \mathrm{a}$ & 1 & 3 & 5 & 6 & 8 & 9 & 11 & 13 & 16 & 28 \\
$45 \mathrm{a}$ & 0 & 1 & 2 & 3 & 5 & 8 & 12 & 16 & 21 & 33 \\
$10 \mathrm{a}$ & 1 & 4 & 6 & 7 & 9 & 10 & 11 & 13 & 15 & 24 \\
$43 \mathrm{a}$ & 1 & 1 & 2 & 4 & 5 & 7 & 10 & 13 & 18 & 38 \\
$30 \mathrm{a} a$ & 2 & 4 & 5 & 6 & 8 & 9 & 11 & 13 & 16 & 26 \\
\hline
\end{tabular}

Аналіз та зіставлення наведених у табл. 2 даних дає змогу виділити п'ять груп об'єктів. Графічна інтерпретація структури запасу сосни звичайної представлених об'єктів, об'єднаних в окремі групи, зображено на рис. 1.

Розподіл запасу стовбурової деревини сосни за рівновеликими частинами деревостану специфічний для кожного об'єкта досліджень і відображає особливості здійснених лісогосподарських захо- дів. Встановлені особливості дали змогу відзначити різні типи формування деревостанів в межax розташування підприємства, що дасть змогу в подальшому врахувати їх для вирощування високопродуктивних та біотично стійких соснових лісостанів. Для кожної групи об'єктів подано додаткову біометричну характеристику кількісного розподілу дерев сосни звичайної за діаметром на висоті 1,3 м. Отримані дані представлено в табл. 3.

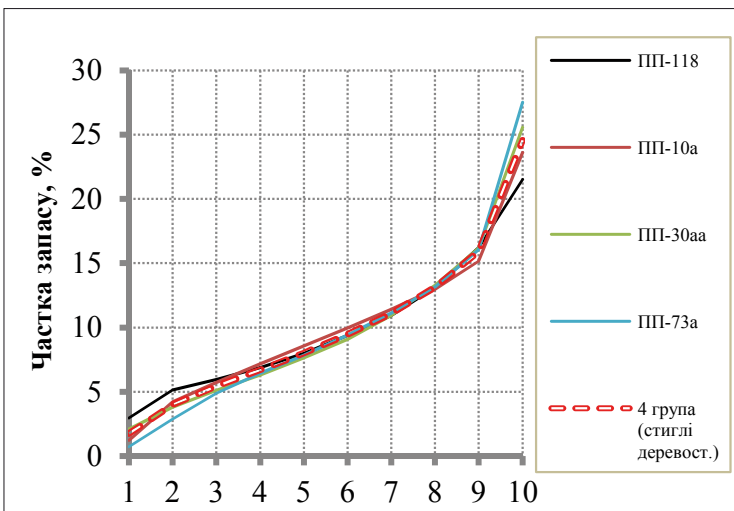

Індекс рівновеликої частини деревостану

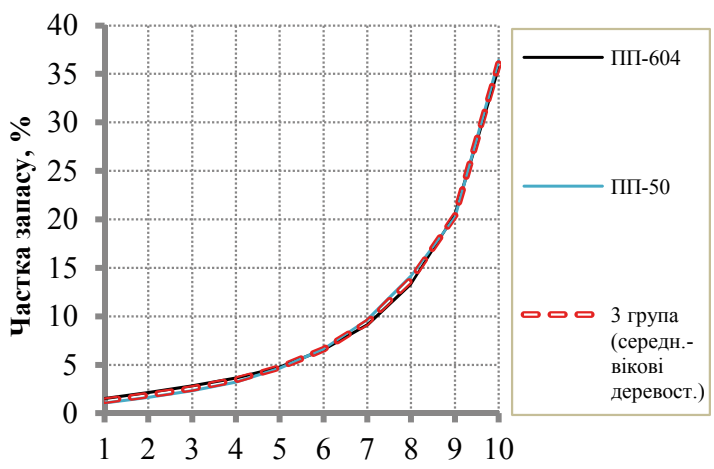

Індекс рівновеликої частини деревостану

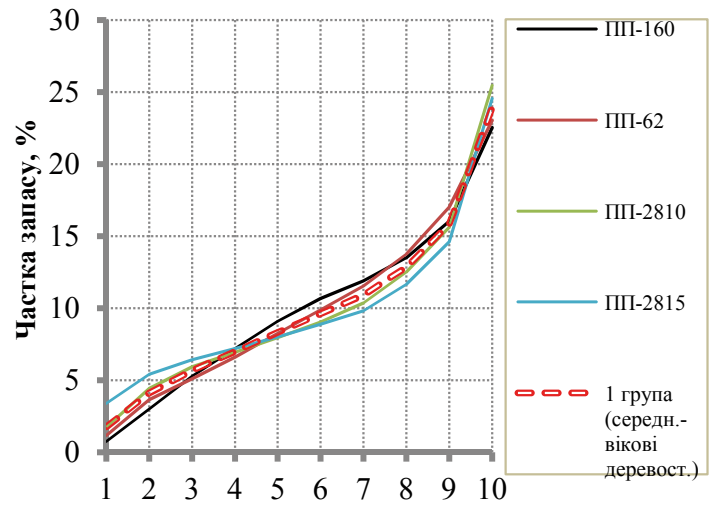

Індекс рівновеликої частини деревостану

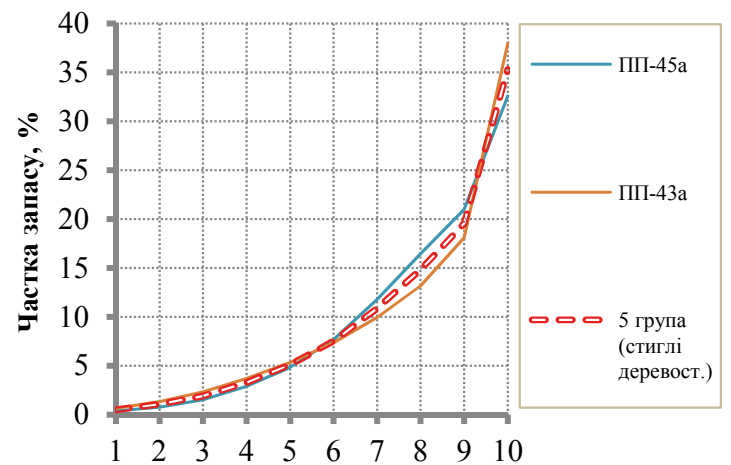

Індекс рівновеликої частини деревостану

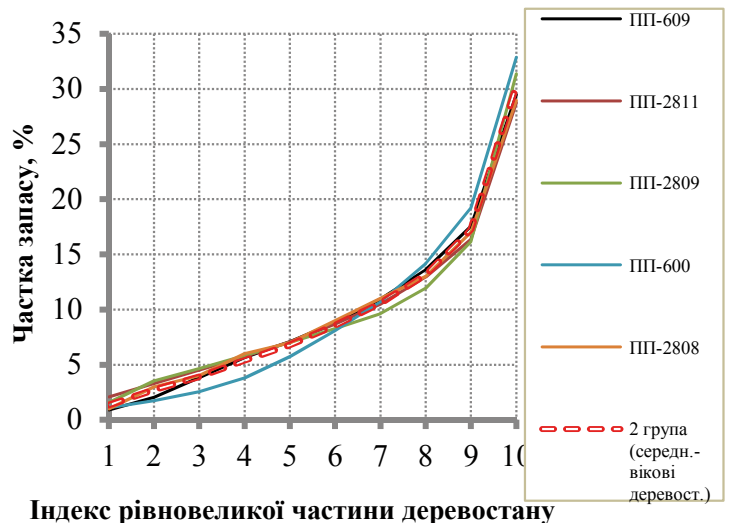

Рис. 1. Розподіл запасу стовбурової деревини сосни звичайної за рівновеликими частинами деревостану та виділеними групами об’єктів 
Поряд з тим відзначено особливості коливання мінімального та максимального діаметра, що дасть змогу здійснити відповідні заходи 3 метою вирощування соснових деревостанів 3 цільовими таксаційними параметрами в межах конкретних лісорослинних умов. Моделі відтворення деревостанів можуть передбачати наявність проміжних етапів, які сприятимуть збагаченню порушених грунтів органічними речовинами та відтворенню їх мікологічної структури.

Відповідно до даних, наведених в табл. 3, необхідно відзначити помітну зміну величини середнього арифметичного діаметра, показників мінливості (коефіцієнт варіації, ліміти) та форми розподілу діаметрів (асиметрія, ексцес), як між групами об'єктів, так і всередині групи.

Відмінності частки запасу за величиною між віковими групами (середньовікові і стиглі), залежно від мінливості діаметрів стовбурів сосни, підтверджено для всіх рівновеликих частин деревостану, за винятком сьомої частини. Графічну інтерпретацію тренду частки запасу сосни в межах рівновеликої частини та вікової групи об'єкту, залежно від мінливості діаметрів стовбурів, проілюстровано на рис. 2 .

У межах рівновеликої частини деревостану та вікової групи об'єктів виявлено значну детермінованість частки запасу мінливістю діаметрів стовбурів. Вона змінюється в межах $42-93 \%$ для середньовікових деревостанів (коефіцієнт кореляції перевищує 0,6) та в межах 52-99\% - для стиглих деревостанів (коефіцієнт кореляції перевищує 0,7). Враховуючи, що соснові деревостани сформовані в одному типі лісорослинних умов, але відносяться до різних груп віку, можна констатувати помітні відмінності у розподілі запасу стовбурової деревини для більшості рівновеликих частин.

Таблиия 3

Біометрична характеристика сосни для виділених груп об'єктів

\begin{tabular}{cccccccc}
\hline Група & Код ПП & $\mathrm{D}_{\mathrm{a}}$ & $\mathrm{Var}$ & $\mathrm{d}_{\min }$ & $\mathrm{d}_{\max }$ & $\mathrm{A}_{\mathrm{s}}$ & $\mathrm{E}_{\mathrm{x}}$ \\
\hline 1 & $160,62,2810,2815$ & $16,9 / 32,0$ & $19,7 / 30,7$ & $8 / 12$ & $28 / 52$ & $-0,41 / 0,98$ & $-0,63 / 1,36$ \\
2 & $2808,2811,2809,609,600$ & $14,2 / 19,0$ & $27,3 / 38,8$ & $8 / 12$ & $28 / 36$ & $0,17 / 0,88$ & $-0,81 / 0,82$ \\
3 & 604, 50 & $12,0 / 13,5$ & $38,6 / 42,2$ & 8 & $24 / 28$ & $0,84 / 0,90$ & $-0,31 /-0,21$ \\
4 & 118, 10a, 30aa, 73a & $19,7 / 32,5$ & $20,3 / 34,9$ & $8 / 16$ & $28 / 64$ & $-0,21 / 0,66$ & $-0,57 / 0,22$ \\
5 & 45a, 43a & $18,6 / 22,4$ & $44,3 / 50,9$ & 8 & $44 / 48$ & $0,33 / 0,63$ & $-1,04 /-0,08$ \\
\hline
\end{tabular}

Примітки. $\mathrm{D}_{\mathrm{a}}$ - середній арифметичний діаметр елемента лісу, см; $\mathrm{V}_{\mathrm{ar}}-$ коефіцієнт варіації, \%; $\mathrm{d}_{\min }$ та $\mathrm{d}_{\max }-$ ліміти, см; $\mathrm{A}_{\mathrm{s}}-$ aсиметрія розподілу діаметрів; $\mathrm{E}_{\mathrm{x}}$ - ексцес розподілу діаметрів.
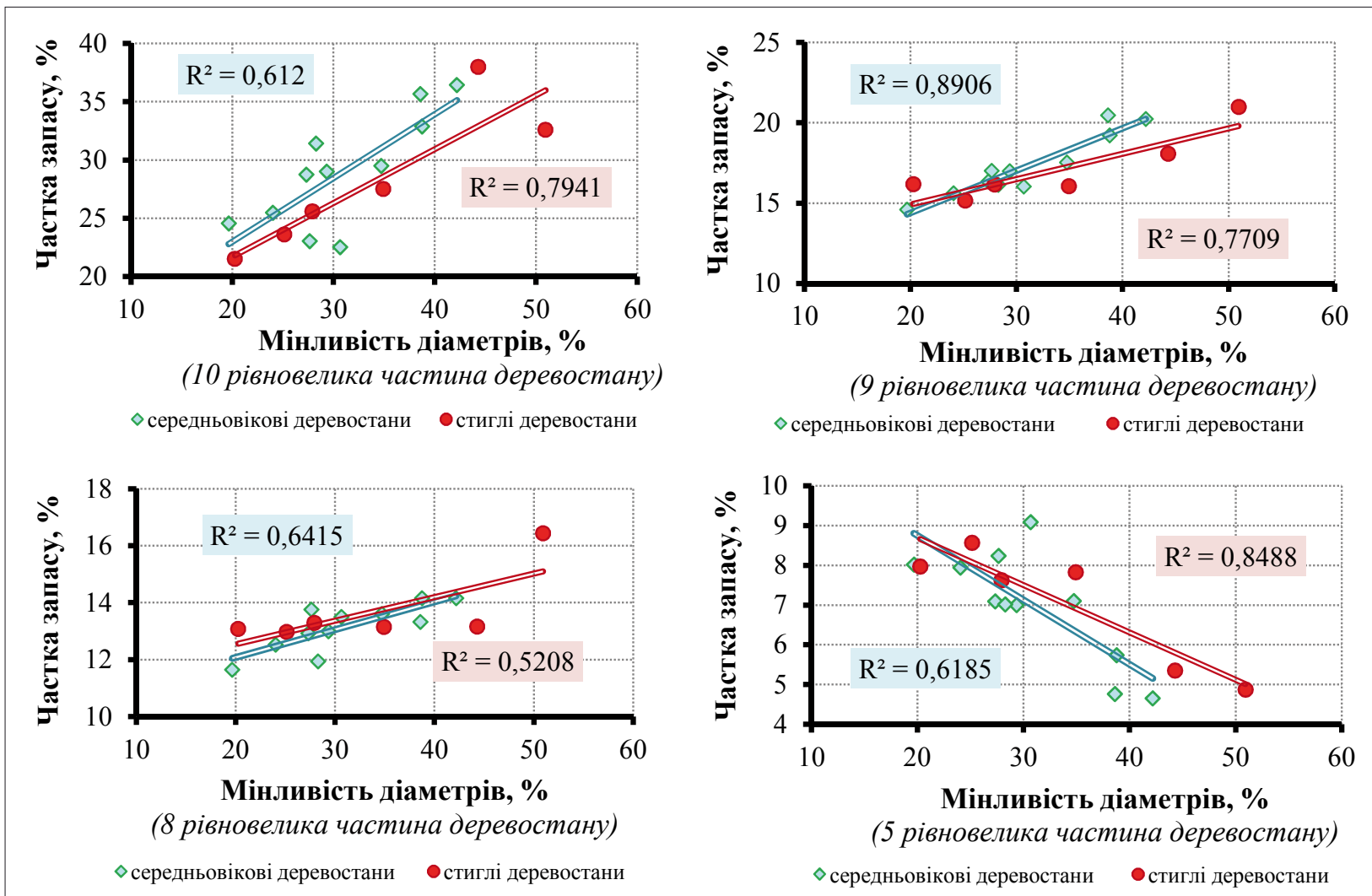

Рис. 2. Розподіл запасу стовбурової деревини сосни звичайної в межах рівновеликої частини деревостану та виділених груп об'єктів залежно від мінливості діаметрів стовбурів 


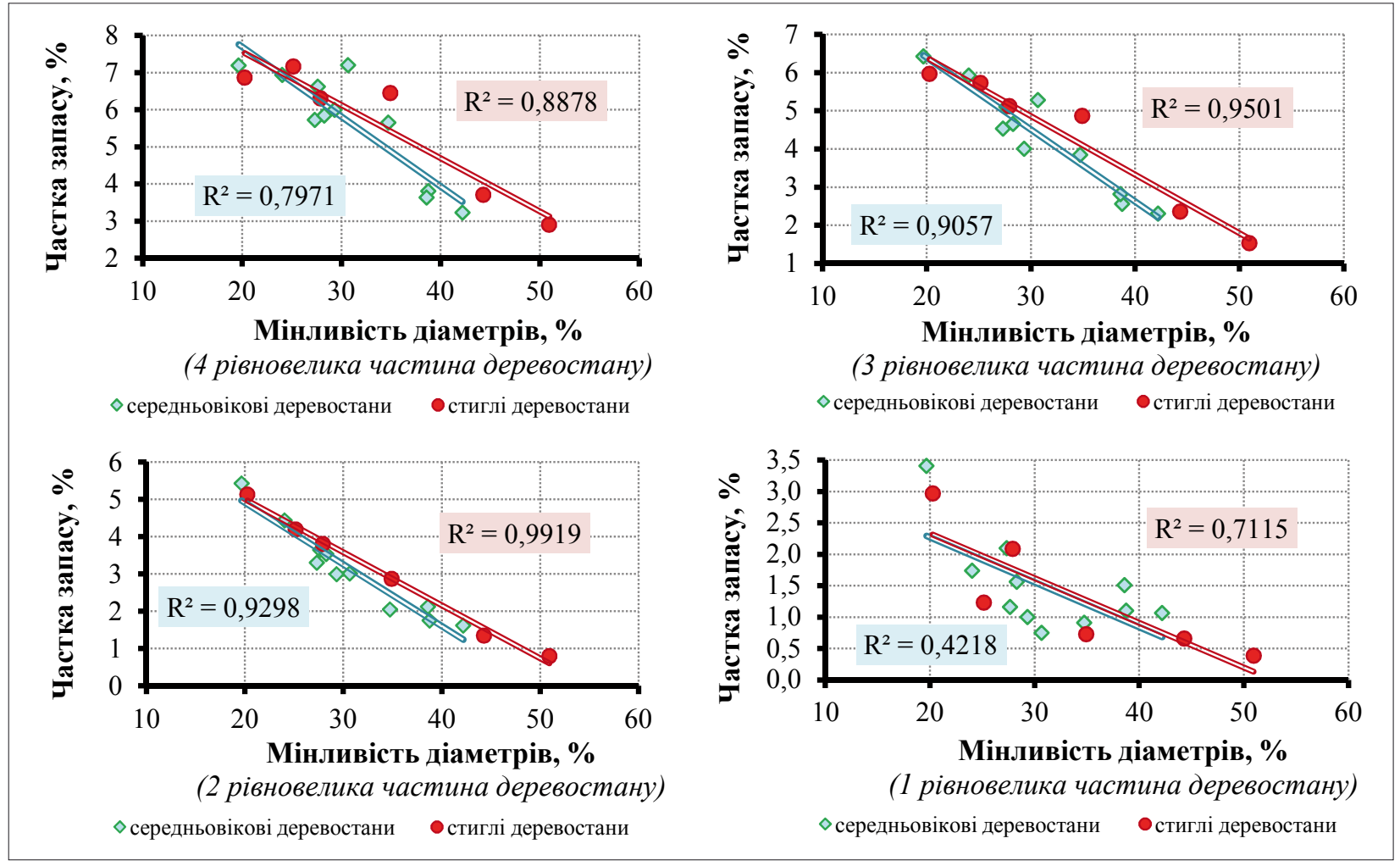

Продовж. рис. 2. Розподіл запасу стовбурової деревини сосни звичайної в межах рівновеликої частини деревостану та виділених груп об'єктів залежно від мінливості діаметрів стовбурів

Встановленні особливості необхідно враховувати під час відтворення лісостанів на порушених видобуванням бурштину ділянках.

Висновки. Встановлено п'ять типів розподілу запасу сосни за рівновеликими частинами деревостану. Різниця частки запасу між групами об'єктів для десятої рівновеликої частини досягає $10-12 \%$, для дев'ятої - 4\%, для інших $-1-3 \%$. Беручи до уваги фактичну величину частки запасу сосни рівновеликої частини деревостану, така відмінність $€$ істотною (особливо для перших шести).

У межах виділених п'яти груп об'єктів встановлено найбільш виразну залежність між величиною частки запасу сосни рівновеликої частини деревостану, групою віку (середньовікові, стиглі) і показником мінливості діаметрів стовбурів. Частка запасу сосни рівновеликої частини деревостану характеризується більшою ентропією, якщо ії дисперсію пояснювати зміною величини інших розглянутих таксаційних та біометричних показників.

Аналіз підтверджує вагомість чинника господарської діяльності (терміни проведення доглядових рубань, інтенсивність вибірки дерев, методи відбору дерев у рубку) на структуру деревного запасу сосни в деревостанах із різним видовим складом, потенційною та фактичною продуктивністю.

Отримані результати типізації розподілу запасу за рівновеликими частинами, таксаційнобіометрична характеристики соснових деревостанів зумовлюють необхідність застосування особливого підходу під час відтворення та планування лісогосподарських заходів й головного користування стиглим деревним запасом на ділянках, порушених розробкою бурштину.

Встановлені особливості структури деревостанів у межах аналізованого підприємства дають змогу опрацювати відповідні моделі формування видового складу, таксаційної структури, інтенсивності проведення доглядових рубань у межах вікових груп 3 метою відтворення мішаних деревостанів за участю характерних кліматичних домішок, що забезпечить нагромадження органічної речовини, збагачення мікологічної структури порушених грунтів та покращення їхніх фізико-механічних властивостей.

\section{References}

Agij, V., Kopiy, S., Fizyk, I., Kahaniak, Yu., \& Kopiy, L. (2016). Types of Distribution of the Stock of Mature Hornbeam-Oak Stands in Transcarpathia. Scientific bulletin of the Ukrainian National Forestry University, 26.8, 16-24. https://doi.org/10.15421/ 40260802 (in Ukrainian).

Gonchar, V., Kopiy, S., Kahaniak, Yu., \& Kopiy, L. (2012). Features of the structure of the stock of birchpine stands in Western Polissia. Scientific Bulletin of National University of Life and Environmental Sciences of Ukraine. Series «Forestry and Ornamental Horticulture», 171 (3), 23-29 (in Ukrainian).

Hordijchuk, M. (2013). Impact of amber extraction on the natural landscapes of the Rivne region. Physical Geography and Geomorphology, 2, 259-262 (in Ukrainian). 
Jonson, N., \& Lion, F. (1980). Statistics and experimental design in science and technology. Data processing methods. Moscow: Science (in Russian).

Kahaniak, Yu. (2006). For-ecast of potential productivity of pine and beech stands. Scientific bulletin of the Ukrainian National Forestry University, 16.6, 39-45. https://nv.nltu.edu.ua/ Archive/2006/16_6/index.htm (in Ukrainian).

Kahaniak, Yu. (2005). Modification of models of normal stock sand absolute completeness for pine stands. Scientific bulletin of the Ukrainian National Forestry University, 15.4, 49-54. https://nv.nltu.edu. ua/Archive/2005/15 4/index.htm (in Ukrainian).

Kahaniak, Yu. (2005). Short-term prediction of taxation indicators of pine stands. Scientific bulletin of the Ukrainian National Forestry University, 15.2, 29-35. https://nv.nltu.edu.ua/Archive/2005/15_2/index.htm (in Ukrainian).

Kopiy, L., Kahaniak, Yu., Gonchar, V., Kopiy, S., Myhailenko, M., Kopiy, M., \& Fizyk, I (2014). Stock dynamics of elementary parts of mixed stands of Western Polissia. Proceedings of the Forestry Academy of Sciences of Ukraine, 12, 140-147. http:// fasu.nltu.edu.ua/index.php/nplanu/article/view/148 (in Ukrainian).

Kopiy, L., Kahaniak, Yu., Meleshchuk O. (2008). Investigation of the structure of the main forest taxation indicators of stands in the fresh oak subsoil of western Polissia. Scientific bulletin of the Ukrainian National Forestry University, 18.11, 115-122. https:// nv.nltu.edu.ua/Archive/2008/18_11/index.htm (in Ukrainian).

Kornienko, V. (2014). Modern technologies of amber extraction from fields. Bulletin of the National University of Water and Environmental Management. Engineering sciences, 1, 462-470 (in Ukrainian).

Kucheriavyy, V. (2010). General ecology. Lviv: The World (in Ukrainian).

Kurepa, S. (2009). Changing of the surface layer of soil due to hydro pump amber extraction in the Banyki tract. In Conservation and Reproduction of the Biodiversity of the Protected Areas, June 11-13. Sarny, Ukraine: Rivne printing house (in Ukrainian).

Reida S. (2015). Degradation of the soil cover as an echo of the amber «fever». In National Science at the Turn of the Ages: Problems and Prospects for Development, 48-51. Pereyaslav-Khmelnitsky, Ukraine: Coll. Science.

Strochynskyy, A. (2006). Ministry of Agrarian Policy of Ukraine. SOW Test areas are forested. Method of laying. Kyiv: Ministry of Agrarian Policy of Ukraine (in Ukrainian).

Strochynskyy, A., \& Kashpor, S. (2007). Unified system of boning of forest plantations. Forest taxation standards. Kyiv: NAU Publishing Center (in Ukrainian).

Strochynskyy, A., Kashpor, S., \& Berezivskyy, L. (2007). The sum of the cross-sectional area sand the stock of tree standsat 1.0. Timber taxation standards (second edition, revised and supplemented). Kyiv: NAU Publishing Center (in Ukrainian).

Tsuryk, E. (2000). Listed taxation of the forest. Lviv: Ukrainian State Forestry University (in Ukrainian).

Tunycia, U. (2002). Ecological Constitution of the Earth. Idea. Concept. Problems. Lviv: Publishing Center of Ivan Franko National University of Lviv (in Ukrainian).

Vorobjov, D. (1953). Types of forests in the European part of the USSR. Kyiv: Publishing House of the Academy of Sciences of the Ukrainian SSR (in Russian).

\section{Структура сосновых древостоев района разработки янтаря в северо-восточной части Западного Полесья}

\author{
Л.И. Копий ${ }^{1}$ Ю.И. Каганяк², С.Л. Копий ${ }^{3}$, \\ В.Н. Сухович ${ }^{4}$, М.Л. Копий ${ }^{5}$, И.В. Физик
}

Хозяйственная деятельность государственного предприятия «Клесовское лесное хозяйство» базируется на основе комплексного использования природных ресурсов, сконцентрированных на

Копий Леонид Иванович - академик Лесной академии наук Украины, доктор сельскохозяйственных наук, профессор, заведующий кафедры экологии. Национальный лесотехнический университет Украины, ул. Генерала Чупринки, 103, г. Львов, 79057, Украина. Тел.: +38-067-750-34-66. E-mail: kop.1@i.ua ORCID https://orcid.org/ 0000-0001-6672-3904

2 Каганяк Юлиан Иосифович - академик Лесной академии наук Украины, доктор сельскохозяйственных наук, профессор кафедры лесной таксации и лесоустройства. Национальный лесотехнический университет Украины, ул. Генерала Чупринки, 103, г. Львов, 79057, Украина. Тел.: +38-067-587-42-66. E-mail: kaganiak@yahoo.ca; y.kaganyak@nltu.edu.ua ORCID http://orcid.org/0000-0002-9215-3922

Копий Сергей Леонидович - член-корреспондент Лесной академии наук Украины, кандидат сельскохозяйственных наук, доцент кафедры лесоводства. Национальный лесотехнический университет Украины, ул. Генерала Чупринки, 103, г. Львов, 79057, Украина. Тел.: +38-097-440-98-20. E-mail: s.kopiy@ email.ua ORCID https://orcid.org//0000-0002-7322-7244

4 Сухович Виталий Николаевич - аспирант кафедры экологии. Национальный лесотехнический университет Украины, ул. Генерала Чупринки, 103, г. Львов, 79057, Украина. Тел.: +38-067362-09-77. E-mail: suhovich_den@ukr.net ORCID: https://orcid. org/ 0000-0001-8701-3135

Копий Мария Леонидовна - кандидат сельскохозяйственных наук, ассистент кафедры экологии. Национальный лесотехнический университет Украины, ул. Генерала Чупринки, 103, г. Львов, 79057, Украина. Тел.: +38-097-440-98-20. E-mail: marykop16@ukr.net ORCID: https://orcid.org/0000-0003-43555543

Физик Игорь Васильевич - член-корреспондент Лесной академии наук Украины, кандидат сельскохозяйственных наук, докторант кафедры экологии. Национальный лесотехнический университет Украины, ул. Генерала Чупринки, 103, г. Львов, 79057, Украина. Тел.: +38-067-362-15-55. E-mail: igor240265@ gmail.com ORCID: https://orcid.org/ 0000-0003-4247-2519 
территории лесного фонда. Лесные экосистемы являются источником древесины и недревесных лесных ресурсов, протектором эрозии лесных почв, климаторегулирующим фактором. Одновременно на территории лесохозяйственного предприятия осуществляется разработка янтаря. Подобное вмешательство в лесную экосистему в будущем будет отображаться на структуре древесного запаса, протекании процесса его накопления деревьями.

Целью исследования является актуализация лесотаксационных показателей сосновых древостоев на участках лесного фонда лесохозяйственного предприятия, сходных по составу и структуре с теми, которые уничтожены в результате разработки янтаря. Объектом исследования являются чистые и смешанные сосновые древостои на землях, не нарушенных разработкой янтаря, в условиях влажной субори на территории лесного фонда ГП «Клесовское лесное хозяйство». Предметом исследования является структура древесного запаса упомянутого объекта.

Первичная информация по объекту получена методом перечислительной таксации. Структурный анализ использует данные распределения количества деревьев элемента леса по ступеням толщины и размерно-качественным категориям (деловые, полуделовые, дровяные и сухостой), а также измеренные в трёх-пяти деревьев высоты для каждой ступени толщины. Инвентаризация территории лесного фонда предприятия выявила семнадцать участков, идентичных по составу и структуре древостоям, уничтоженным разработкой минерала. Исследованные средневозрастные и спелые сосновые древостои по составу чистые, либо с небольшой примесью (до 1-3 единиц) берёзы, дуба, осины и ольхи. Сосновые древостои характеризуются значительным колебанием индекса класса бонитета (от IV до $\mathrm{I}^{\mathrm{c}}$ ) и относительной полноты (от 0,2 до 0,7).

Запас в пределах элемента леса распределен на десять равновеликих частей. Установлена изменчивость части запаса сосны обыкновенной, распределённой по равновеликим частям. Выявлено пять типов распределения запаса сосны по равновеликим частям древостоя. Тип распределения части запаса сосны детерминирован древесной породой, группой возраста и показателем вариации диаметра ствола. Разница части запаса между группами объектов для десятой равновеликой части составляет 10-12\%, для девятой $-4 \%$, для других структурных составляющих $-1-3 \%$.

Структурный анализ подтверждает весомость лесохозяйственных мероприятий (своевременное проведение рубок ухода, интенсивность выборки деревьев, метод отбора деревьев в рубку) на распределение запаса сосны по равновеликим частям древостоя. Разработка янтаря на лесных территориях является дополнительным негативным фактором, который необходимо учитывать при восстановлении лесных насаждений, разработке системы рубок формирования и оздоровления древостоев на участках после разработки янтаря.

Ключевые слова: структура древостоев; запас; равновеликая часть; сосна; показатель; изменчивость.

\section{Structure of pine stands in the area of amber production at the North-Eastern part of the West Polissya}

\author{
L. Kopiy ${ }^{1}$, Yu. Kahaniak², S. Kopiy ${ }^{3}$, V. Suhovych ${ }^{4}$, \\ M. Kopiy ${ }^{5}$, I. Fizyk ${ }^{6}$
}

The economic activities of the Klesiv State Forestry Enterprise are guided by the theoretical foundations of the integrated use of natural resources, which are concentrated on the territory of the forest fund. Forest ecosystems are a source of wood and non-forest forest resources, a factor forest soil protector against erosion and a climate-regulating. At the same time, amber is being mined on the territory of forestry enterprise. Such an intervention in the forest ecosystem will be reflected subsequently at the wood stock structure, and the process of its accumulation by trees.

Leonid Kopiy - Full Member of the Forestry Academy of Sciences of Ukraine, Doctor of Agricultural Sciences, Head of the Department of Ecology, Professor Ukrainian National Forestry University, General Chuprynka str., 103, Lviv, 79057, Ukraine. Tel.: +38-067-750-34-66. E-mail: kop.1@i.ua ORCID https:// orcid.org/ 0000-0001-6672-3904

2 Yulian Kahaniak - Full Member Member of the Forestry Academy of Sciences of Ukraine, Doctor of Agricultural Sciences, Professor of the Department of Forest Taxation and Forest Management. Ukrainian National Forestry University, General Chuprynka str., 103, Lviv, 79057, Ukraine. Tel.: +38-067-587-42-66. E-mail: kaganiak@yahoo.ca; y.kaganyak@nltu.edu.ua ORCID http:// orcid.org/0000-0002-9215-3922

Serhiy Kopiy - Corresponding Member of the Forestry Academy of Sciences of Ukraine, PhD in forestry, Associate Professor, Department of Forestry. Ukrainian National Forestry University, General Chuprynka str., 103, Lviv, 79057, Ukraine. Tel.: +38097-440-98-20. E-mail: s.kopiy@email.ua ORCID https://orcid. org//0000-0002-7322-7244

4 Vitalii Suhovych - postgraduate student of the Department of Ecology Ukrainian National Forestry University, General Chuprynka str., 103, Lviv, 79057, Ukraine. Tel.: +38-067-362-0977. E-mail:suhovich_den@ukr.net ORCID https://orcid.org/00000001-8701-3135

Maria Kopiy - PhD in ecology, Assistant Professor, Department of Ecology. Ukrainian National Forestry University, General Chuprynka str., 103, Lviv, 79057, Ukraine. Tel.: +38-097-440-9820. E-mailmarykop16@ukr.net ORCID https://orcid.org/ 00000003-4355-5543

6 Igor Fizyk - Corresponding Member of the Forestry Academy of Sciences of Ukraine, PhD in forestry, Doctoral Student, Department of Ecology Ukrainian National Forestry University, General Chuprynka str., 103, Lviv, 79057, Ukraine. Tel.: +38-067362-15-55. E-mail; igor240265@gmail.com ORCID https://orcid. org/ 0000-0003-4247-2519 
The aim of the study is to update the forest biometry indicators of pine stands in the forest fund forestry areas, which are characterized by the composition and structure that were destroyed as a result of amber mining and further analysis of the structure of wood stock. The object of the study is pure and mixed pine stands on lands that are not disturbed by amber mining, in humid «subir» in the forest fund of the Klesiv State Forestry Enterprise. The subject of the study is the stock structure of the mentioned object.

Due to the active extraction of amber, not only the structure of stands, but also soil conditions, soil moisture and other components (forest plants, hydrological conditions, terrain) are significantly disturbed. The extraction of minerals by using of powerful water pumps leads to a significant disturbance of the terrain, the formation of significant abysses, intra-soil voids, which creates significant threats for forestry activities.

Primary information about the object was obtained by the method of enumeration biometry. Structural analysis uses data on the distribution of the number of trees of a forest element beyond the thickness steps and size and quality categories as well as measured in three to five height trees for each thickness step. An inventory of the territory of the forest fund of the enterprise revealed seventeen sections identical for the composition and structure of stands destroyed by the amber mining. The middle-aged and ripe pine stands are clean or with a small admixture (up to 1-3 units) of birch, oak, aspen and alder. Pine stands are characterized by significant fluctuations in the index of bonitet class (from IV to $\mathrm{I}^{\mathrm{c}}$ ) and relative completeness (from 0.2 to 0.7 ).

The stock within the forest element is divided into ten equal parts. The variability of a part of the stock of common pine, distributed beyond equal parts, is established. It was revealed that there are five types of pine stock distribution beyond equal parts of the stand. The type of distribution of the part of the pine stock is determined by the tree species, age group and t index of trunk diameter variation. The difference in the part of the stock between groups of objects for the tenth equal part is $10-12 \%$, for the ninth $-4 \%$, for other structural components $-1-3 \%$.

Structural analysis confirms the importance of silvicultural activities (timely felling, the intensity of tree sampling, the method of selecting trees for felling) on the distribution of pine stocks over equal parts of the forest stand. The amber mining in forest areas is an additional negative factor that must be taken into account when restoring forest stands, and developing a felling system for the formation and rehabilitation of stands in areas after the amber mining.

An important task in the reproduction of highly productive stands in areas after amber extraction is to ensure the proper stands composition, timely cutting care in order to preserve the characteristic climatic impurities and timely removal from the plantations of birch trees hanging in the bush.

Key words: forest structure; stock; equal parts; pine; variability. 